\title{
2010 and beyond for Lepidoptera
}

\author{
J. W. Dover · M. S. Warren - T. G. Shreeve
}

Received: 21 October 2010/ Accepted: 10 November 2010/Published online: 26 November 2010

(C) Springer Science+Business Media B.V. 2010

The Convention on Biological Diversity (CBD) was an outcome of the 'Earth Summit' held in Rio de Janeiro in 1992. In 2002 the Convention committed the European Union (EU) and (currently) 192 other countries "to achieve by 2010 a significant reduction of the current rate of biodiversity loss at the global, regional and national level" (Anonymous 2010). The EU set an even more ambitious target: “...to protect and restore habitats and natural systems and halt the loss of biodiversity by 2010..." (Anonymous 2001). In March 2010, Butterfly Conservation held its 6th International Symposium on the topic, 'The 2010 Target and Beyond for Lepidoptera', to assess progress towards the target, report advances in conservation science, and look to the future. This volume presents a collection of papers from that meeting.

Evidence presented at the Symposium from across the world was bleak, with no evidence that the EU and CBD target had been met (Asher et al. 2011; Brereton et al. 2011; Caritg et al. 2011; Fox et al. 2011; Groenendijk and Ellis 2011; Lewis and Senior 2011; Nakamura 2011; Sáfián et al. 2011; Stefanescu et al. 2011). At the global scale the general trend for Lepidoptera is one of decline, and the overall trend for biodiversity is of a continuous and accelerating decline. In May 2010 the CBD published its

J. W. Dover $(\bowtie)$

Institute for Environment, Sustainability and Regeneration,

Staffordshire University, College Road,

Stoke-on-Trent ST4 2DE, UK

e-mail: j.w.dover@staffs.ac.uk

M. S. Warren

Butterfly Conservation, Manor Yard, Wareham BH20 5QP, UK

T. G. Shreeve

School of Life Sciences, Oxford Brookes University,

Headington, Oxford OX3 OBP, UK overall assessment of progress towards the 2010 target and reported failure (Anonymous 2010). The 2002 CBD and EU targets were ambitious, and, despite not being met, they did manage to place conservation and biodiversity firmly on global and national political and development agendas and provided mechanisms for raising public awareness.

Failure can be a powerful stimulus to renewed action, especially if the reasons for failure are identified. New CBD 2020 targets are now being formulated (Djoghlaf 2010) alongside a vision for 2050. Initial progress suggests there will be a much closer integration of biodiversity with climate change adaptation/mitigation, ecosystem services, human health and the economic benefits of biodiversity (Djoghlaf 2010). Papers in this collection examine some of the likely impacts of climate change on Lepidoptera (e.g. de Vries et al. 2011; Wilson and Maclean 2011). Whilst climate change is an issue and will become an even bigger issue in the future, biodiversity loss is already a problem and likely to become worse unless measures are taken now. For some Lepidoptera there is a real and imminent threat of local, regional and global extinction. For such species, urgent action is needed now and climate change is a distant threat. The papers here outline the issues, and some demonstrate how approaches based on sound conservation science can improve the status of species, both preventing imminent extinction and making populations more resilient to future climate change (e.g. Ellis et al. 2011; Porter and Ellis 2011).

Meeting the new CBD targets, will require well researched solutions and this volume contains contributions to the challenges ahead under the broad headings of the Science of Conservation Management and Landscape-scale Conservation. Jeremy Thomas, for example, distills a lifetime of experience working with endangered species to identify key factors of importance in butterfly conservation 
(Thomas et al. 2011). Many contributions are speciesspecific in their approach e.g. Botham et al. (2011) whilst other papers examine how we can manipulate the agricultural environment to soften the impacts of intensive agriculture on a broad range of 'wider countryside' species (e.g. Haaland and Bersier 2011).

In 2002 when CBD participants committed themselves to the 2010 target, it was increasingly recognised that, whilst the optimal management of individual habitat patches will always underpin conservation action, long-term persistence of species in a given area was a landscape-scale issue. The spatial organisation of resources within a landscape is now recognised as a prime determinant of species' distributions and persistence (e.g. Williams 2011) and targeted action on the ground is demonstrating that such approaches can yield excellent results (e.g. Ellis et al. 2011). Whilst much landscape-scale conservation is aimed at repairing anthropogenic impacts that created extremely fragmented habitats, it is encouraging that naturally fragmented systems are being examined for cues to understand species responses to such systems (Swengel and Swengel 2011). Understanding species' responses to fragmented landscapes is exceptionally difficult, as experimentation at such a scale is often impossible, and even intensive agricultural landscapes rarely correspond to the binary patch/matrix simplicity of early modelling (Dennis et al. 2003; Dover and Settele 2009). In the absence of detailed data on species' behavioural responses in the 'matrix' between habitat patches and recognising that this is a complex issue to address, Shreeve and Dennis (2011) suggest that using agri-environment schemes to increase landscape heterogeneity and disturbance may be a pragmatic approach to improve dispersal and access to resources.

Agri-environment schemes have not always been well thought-out (Warren et al. 2005), and can have negative consequences (e.g. Konvička et al. 2008) although they are probably our best tool to work with in intensively managed landscapes (Settele et al. 2009). It is promising therefore that Brereton et al. (2011) reports clear evidence that targeted Higher Level agri-environment schemes are slowing, and in some cases reversing, the decline of threatened butterflies in the UK Schemes must be designed and implemented on the basis of science if they are to be effective in conserving biodiversity. In intensive agricultural areas the pressure is to maintain production at the expense of agri-environment schemes and in the EU they remain vulnerable to changes in the Common Agricultural Policy (CAP). In landscapes that are less intensively managed (extensive or cultural landscapes) there is a different problem: supporting existing agricultural systems that currently deliver some of the highest quality areas in terms of biodiversity (Dover et al. 2011a). This is not an issue of developing a new margin mixture or management prescription; in Europe it is about radically reforming the (CAP) and developing support measures that can underpin existing High Nature Value Farmland-it is a matter of socioeconomics and social justice (see Dover et al. 2011b).

Reforming the CAP is just one of the ten challenges that Warren and Bourn (2011) have identified as needing to be addressed if the new CBD 2020 targets and 2050 vision are to be realised. The challenges are undeniably tough; but the global community must rise to them, and we as conservationists need to fulfil the faith that is held in us and our ability to help effect change (see Attenborough 2011). We have much of the science to know what will be effective; a crucial issue now is how we apply that science to be effective against one of the greatest threats facing the planet: the rapid loss of biodiversity.

Acknowledgments The Symposium and its proceedings were partfunded by DG Environment. The opinions expressed are those of the authors and do not necessarily reflect those of the funders.

\section{References}

Anonymous (2001) Presidency conclusions. Götegorg European Council 15 and 16 June 2010 SN 200/1/01 REV 1. EU, Brussels

Anonymous (2010) Global biodiversity outlook 3-executive summary. Secretariat of the Convention on Biological Diversity, Montréal

Asher J, Fox R, Warren MS (2011) British butterfly distributions and the 2010 target. J Insect Conserv. doi: 10.1007/s10841-0109346-7

Attenborough D (2011) Opening address by Sir David Attenborough, president of butterfly conservation, to the 6th international symposium reading, 25-28 March 2010. J Insect Conserv

Botham MS, Ash D, Aspey N, Bourn NAD, Bulman CR, Roy DB, Swain J, Zannese A, Pywell RF (2011) The effects of habitat fragmentation on niche requirements of the marsh fritillary, Euphydryas aurinia, (Rottemburg, 1775) on calcareous grasslands in southern UK. J Insect Conserv. doi: 10.1007/s10841010-9344-9

Brereton TM, Roy DB, Middlebrook I, Botham M, Warren M (2011) The development of butterfly indicators in the United Kingdom and assessments on 2010. J Insect Conserv. doi: 10.1007/s10841010-9333-z

Caritg R, Domènech M, Dantart J, Jubany J (2011) Andorran butterfly monitoring scheme. doi: 10.1007/s10841-010-9352-9

de Vries HH, Ens SH, de Graaf G, Teunissen L, van der Velde R, Vogelaar L, Winterink A, Visser ME (2011) Synchronisation of egg hatching of brown hairstreak (Thecla betulae) and budburst of blackthorn (Prunus spinosa) in a warmer future. J Insect Conserv. doi: 10.1007/s10841-010-9355-6

Dennis RLH, Shreeve TG, Van DycK H (2003) Towards a functional resource-based concept for a habitat: a butterfly biology viewpoint. Oikos 102:417-426

Djoghlaf A (2010) Statement by Mr Ahmed Djoghlaf, executive secretary of the convention on biological diversity on the occasion of the informal expert workshop on the updating of the strategic plan of the convention for the post-2010 period, London 18 January 2010. Secretariat of the Convention on Biological Diversity, UNEP, Montreal 
Dover J, Settele J (2009) The influences of landscape structure on butterfly distribution and movement: a review. J Insect Conserv 13:3-27

Dover JW, Rescia A, Fungariño S, Fairburn J, Carey P, Lunt P, Arnot C, Dennis RLH, Dover CJ (2011a) Land-use, environment, and their impact on butterfly populations in a mountainous pastoral landscape: individual species distribution and abundance. J Insect Conserv. doi: 10.1007/s10841-010-9338-7

Dover JW, Spencer S, Collins S, Hadjigeorgiou I, Rescia A (2011b) Grassland butterflies and low intensity farming in Europe

Ellis S, Wainwright D, Berney F, Bulman C, Bourn N (2011) Landscape-scale conservation in practice: lessons from northern England, UK. J Insect Conserv. doi: 10.1007/s10841-010-9324-0

Fox R, Randle Z, Hill L, Anders S, Wiffen L, Parsons MS (2011) Moths count: recording moths for conservation in the UK. J Insect Conserv. doi: 10.1007/s10841-010-9309-z

Groenendijk D, Ellis WN (2011) The state of the Dutch larger moth fauna. J Insect Conserv. doi: 10.1007/s10841-010-9326-y

Haaland C, Bersier LF (2011) What can sown wildflower strips contribute to butterfly conservation?: an example from a Swiss lowland agricultural landscape. J Insect Conserv. doi: 10.1007/s 10841-010-9353-8

Konvička M, Beneš J, Cizek O, Kopecek F, Konvicka O, Vitaz L (2008) How too much care kills species: grassland reserves, agrienvironmental schemes and extinction of Colias myrmidone (Lepidoptera: Pieridae) from its former stronghold. J Insect Conserv 12:519-525

Lewis O, Senior MJM (2011) Assessing conservation status and trends for the world's butterflies: the sampled red list index approach. J Insect Conserv. doi: 10.1007/s10841-010-9329-8

Nakamura Y (2011) Conservation of butterflies in Japan: status, actions and strategy. J Insect Conserv. doi: 10.1007/s10841-0109299-x

Porter K, Ellis S (2011) Securing viable metapopulations of the Marsh Fritillary butterfly, Euphydryas aurinia, (Lepidoptera: Nymphalidae) in Northern England. J Insect Conserv. doi: 10.1007/s 10841-010-9328-9
Sáfián S, Csontos G, Winkler D (2011) Butterfly community recovery in degraded rainforest habitats in the upper Guinean forest zone (Kakum Forest, Ghana). J Insect Conserv. doi: 10.1007/s 10841-010-9343-x

Settele J, Dover J, Dolek M, Konvička M (2009) Butterflies of European ecosystems: impact of land use and options for conservation management. In: Settele J, Shreeve T, Konvička M, Van Dyck H (eds) Ecology of butterflies in Europe. CUP, Cambridge, pp 353-370

Shreeve TG, Dennis RLH (2011) Landscape scale conservation: resources, behaviour, the matrix and opportunities. J Insect Conserv. doi: 10.1007/s10841-010-9338-7

Stefanescu C, Torres I, Jubany J, Páramo F (2011) Recent declines of butterflies in north-east Spain following habitat and climate change. J Insect Conserv. doi: 10.1007/s10841-010-9325-Z

Swengel AB, Swengel SR (2011) High \& dry or sunk \& dunked: lessons for tallgrass prairies from quaking bogs. J Insect Conserv. doi: 10.1007/s10841-010-9335-x

Thomas JA, Simcox DJ, Hovestadt T (2011) Evidence based conservation of butterflies. J Insect Conserv. doi: 10.1007/s 10841-010-9341-z

Warren MS, Bourn N (2011) Ten conservation challenges for 2010 and beyond to conserve Lepidoptera in Europe. J Insect Conserv. doi: 10.1007/s10841-010-9356-5

Warren M, Brereton T, Wigglesworth T (2005) Do agri-environment schemes help butterflies? Experience from the UK. In: Kühn E, Feldmann R, Thomas JA, Settele J (eds) Studies on the ecology and conservation of butterflies in Europe, Vol 1: general concepts and case studies. Moscow, Pensoft, pp 121-123

Williams MR (2011) Habitat resources, remnant vegetation condition and area determine distribution patterns and abundance of butterflies and day-flying moths in a fragmented urban landscape, south-west Western Australia. J Insect Conserv. doi: 10.1007/s10841-010-9307-1

Wilson RJ, Maclean IMD (2011) Recent evidence for the climate threat to Lepidoptera and other insects. J Insect Conserv. doi: 10.1007/s10841-010-9342-y 